\title{
Correction to: From Africa to the Alps: risk assessment on an invasion by Cacyreus marshalli (Butler, 1898)
}

\section{Federica Paradiso ${ }^{1}$. Francesca Martelli ${ }^{1} \cdot$ Cristiana Cerrato $^{2} \cdot$ Silvia Ghidotti $^{2}$ (D) $\cdot$ Ramona Viterbi $^{2} \cdot$ Sara Canterino $^{3}$.} Chiara Ferracini ${ }^{4} \cdot$ Simona Bonelli ${ }^{1}$

Published online: 22 March 2019

๑) Springer Nature Switzerland AG 2019

\section{Correction to: Journal of Insect Conservation https://doi.org/10.1007/s10841-018-00124-8}

The original publication of this article unfortunately contained an error.

The surnames and forenames of the author group were swapped. The correct author group is given in this correction.

Publisher's Note Springer Nature remains neutral with regard to jurisdictional claims in published maps and institutional affiliations.

The original article can be found online at https://doi.org/10.1007/ s10841-018-00124-8.

Silvia Ghidotti

silvia.ghido@gmail.com

1 DBIOS, Department of Life Sciences and Systems Biology,

University of Turin, Turin, Italy

2 Gran Paradiso National Park, Turin, Italy

3 Nino Costa Secondary School - Chiavazza - IC Biella II, Biella, Italy

4 DISAFA, Department of Agricultural, Forest and Food Sciences, University of Turin, Turin, Italy 